\title{
Familial Ligand-Defective Apolipoprotein B Identification of a New Mutation That Decreases LDL Receptor Binding Affinity
}

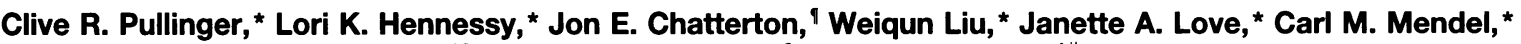 \\ Philip H. Frost, ${ }^{\ddagger}$ Mary J. Malloy, ${ }^{\ddagger}{ }^{\prime}$ Verne N. Schumaker, ${ }^{`}$ and John P. Kane ${ }^{\ddagger \|}$ \\ ${ }^{*}$ Cardiovascular Research Institute, ${ }^{\ddagger}$ Department of Medicine, ${ }^{\S}$ Department of Pediatrics, and "Department of Biochemistry and \\ Biophysics, University of California, San Francisco, California 94143; and "Department of Chemistry and Biochemistry, University of \\ California, Los Angeles, California 90024
}

\begin{abstract}
Detection of new ligand-defective mutations of apolipoprotein $B($ apoB) will enable identification of sequences involved in binding to the LDL receptor. Genomic DNA from patients attending a lipid clinic was screened by singlestrand conformation polymorphism analysis for novel mutations in the putative LDL receptor-binding domain of apoB-100. A 46-yr-old woman of Celtic and Native American ancestry with primary hypercholesterolemia (total cholesterol [ TC] 343 mg/dl; LDL cholesterol [LDL-C] 241 mg/ dl) and pronounced peripheral vascular disease was found to be heterozygous for a novel $\mathbf{A r g}_{3531} \rightarrow$ Cys mutation, caused by a $C \rightarrow T$ transition at nucleotide 10800 . One unrelated 59 yr-old man of Italian ancestry was found with the same mutation after screening 1,560 individuals. He had coronary heart disease, a TC of $310 \mathrm{mg} / \mathrm{dl}$, and an LDL-C of $212 \mathrm{mg}$ / dl. A total of eight individuals were found with the defect in the families of the two patients. They had an age- and sex-adjusted TC of $240 \pm 14 \mathrm{mg} / \mathrm{dl}$ and LDL-C of $169 \pm 10$ $\mathrm{mg} / \mathrm{dl}$. This compares with eight unaffected family members with age- and sex-adjusted TC of $185 \pm 12 \mathrm{mg} / \mathrm{dl}$ and LDL$\mathrm{C}$ of $124 \pm 12 \mathrm{mg} / \mathrm{dl}$. In a dual-label fibroblast binding assay, LDL from the eight subjects with the mutation had an affinity for the LDL receptor that was $63 \%$ that of control LDL. LDL from eight unaffected family members had an affinity of $91 \%$. By way of comparison, LDL from six patients heterozygous for the $\operatorname{Arg}_{3500} \rightarrow$ Gln mutation had an affinity of $36 \%$. The percentage mass ratio of the defective $\mathrm{Cys}_{3531} \mathrm{LDL}$ to normal LDL was 59:41, as determined using the mAb MB19 and dynamic laser light scattering. Thus, the defective LDL had accumulated in the plasma of these patients. Using this mass ratio, it was calculated that the defective Cys $_{3531}$ LDL particles bound with $27 \%$ of normal affinity. Deduced haplotypes using 10 apoB gene markers showed
\end{abstract}

J. E. Chatterton's present address is Department of Biology, Massachusetts Institute of Technology, Cambridge, MA 02139. C. M. Mendel's present address is Department of Clinical Pharmacology, Merck \& Co., Rahway, NJ 07065-0914. Address correspondence to Clive R. Pullinger, Cardiovascular Research Institute, University of California, San Francisco, Box 0130, San Francisco, CA 94143-0130. Phone: 415-476-1155; FAX: 415-476-2283.

Received for publication 14 February 1994 and in revised form 11 November 1994.

J. Clin. Invest.

(c) The American Society for Clinical Investigation, Inc. 0021-9738/95/03/1225/10 \$2.00

Volume 95, March 1995, 1225-1234 the $\operatorname{Arg}_{3531} \rightarrow$ Cys alleles to be different in the two kindreds and indicates that the mutations arose independently. The $\operatorname{Arg}_{3531} \rightarrow$ Cys mutation is the second reported cause of familial ligand-defective apoB. (J. Clin. Invest. 1995. 95:12251234.) Key words: apolipoprotein $B$ - atherosclerosis • hypercholesterolemia $\cdot$ haplotype $\cdot$ genetic mutation

\section{Introduction}

Approximately $70 \%$ of the LDL particles removed from the circulation are cleared by the liver (1), and about $80 \%$ of this uptake is through the LDL receptor; the remainder is by a nonspecific low affinity process (1). The high affinity interaction between LDL and the LDL receptor occurs via apolipoprotein B-100 (apoB-100) and is largely responsible for regulating plasma levels of LDL (1). A large number of mutations (at least 150 ) in the LDL receptor gene have been reported that cause familial hypercholesterolemia (FH), ${ }^{1}$ an autosomal codominant disorder characterized by elevated LDL levels, the frequent presence of tendon xanthomas, and premature coronary heart disease (2). The first indication that a defect in apoB-100 can lead to a phenotype similar to $\mathrm{FH}$ was the observation of decreased fractional catabolic rates of autologous LDL compared with homologous LDL in five subjects (3). It was subsequently shown that LDL from one individual possessed only $32 \%$ of normal binding affinity to LDL receptors on fibroblasts (4). Such a defect might be expected to lead to less severe hypercholesterolemia than in FH since the rate of removal of VLDL remnants by the LDL receptor should not be affected, being mediated by apoE; hence the proportion of remnants converted to $L D L$ should be unchanged. To date, only a single mutation of apoB- 100 has been reported that causes this disorder (familial ligand-defective apoB), a CGG to CAG change in codon 3500 , resulting in the substitution of glutamine for arginine (5). Patients with this autosomal codominant disorder, as predicted, have circulating levels of LDL cholesterol that are generally lower than those seen in FH, although there is extensive overlap. The mean level of LDL cholesterol for a total of 117 individuals heterozygous for the $\operatorname{Arg}_{3500} \rightarrow$ Gln mutation, in five reports, was $245 \mathrm{mg} / \mathrm{dl}$ (6-10). This compares with 312 $\mathrm{mg} / \mathrm{dl}$ for 153 subjects with heterozygous $\mathrm{FH}$ and $122 \mathrm{mg} / \mathrm{dl}$ for 313 control individuals (11).

Since it is likely that other mutations of apoB exist that cause familial ligand-defective apoB, our aim was to develop

1. Abbreviations used in this paper: ASO, allele-specific oligonucleotide; FH, familial hypercholesterolemia; HVR, hypervariable region; SSCP, single-strand conformation polymorphism. 
a technique to screen patients for novel mutations in the putative receptor-binding domain. We adopted a strategy using singlestrand conformational polymorphism (SSCP) analysis $(12,13)$ to screen genomic DNA. SSCP analysis has been used to detect mutations in a number of genes (14-16).

The precise regions of apoB responsible for binding to the LDL receptor remain to be determined. However, the area flanking the thrombin cleavage site at residue 3249 is though to be involved $(17,18)$. Within this area there are two regions, 3147-3157 and 3359-3367, both rich in positive electrostatic charge, with close homology with the LDL receptor-binding domain of apoE. These are included in the domain (residues 2835-4189) shown by antibody studies to include sequences responsible for interaction with the receptor (19). Together with what is known about the $\operatorname{Arg}_{3500} \rightarrow$ Gln mutation, this has led to a general acceptance that residues 3130-3630 account for the major part of the binding affinity (20). Regions outside this area may also contribute $(20,21)$. Using SSCP, we screened nucleotides 9213-11324 (codons 3002-3705). A portion of this region (10095-10773) was shown, in 39 hypercholesterolemic and 14 control subjects, to be highly conserved (22).

We report the discovery of a novel apoB mutation in the putative receptor-binding domain in two unrelated kindreds, the effect on the binding of LDL to the LDL receptor in a newly described dual-label fibroblast binding assay (23), and the mass ratio of the defective LDL to normal LDL as determined by dynamic laser light scattering. apoB gene haplotyping was performed to examine the chromosomal background of the mutation in the two families. In addition, LDL receptor gene markers were studied to determined whether there was cosegregation of this locus with the hypercholesterolemia.

\section{Methods}

Preparation of genomic DNA. Genomic DNA is routinely prepared from whole blood (24) drawn from patients that attend the Lipid Clinic of the University of California, San Francisco.

Lipid profiles. Lipid analyses were performed from blood drawn from fasting individuals as described previously $(25,26)$ with the exception that serum levels of HDL cholesterol and triglyceride were determined after precipitation of LDL and VLDL with $\mathrm{MgCl}_{2}$ and dextran sulfate, and levels of LDL cholesterol and triglyceride were calculated as the levels in total serum minus that in VLDL plus HDL. When appropriate, serum levels of total cholesterol and LDL cholesterol were adjusted for age (to $25 \mathrm{yr}$ ) and gender by nonlinear regression analysis using data in the Lipid Research Clinics Population Studies Data Book (27).

Detection of SSCPs. A 522-bp region of exon 26 of the apoB gene from nucleotide 10469 to 10990 was amplified, using oligonucleotides 88 and 94, from genomic DNA prepared from patients attending the Lipid Clinic (the oligonucleotides used in these studies are listed in Table I). The reactions were performed in $50 \mathrm{mM}$ Tris- $\mathrm{HCl}, \mathrm{pH} 9$ (at $\left.25^{\circ} \mathrm{C}\right), 20 \mathrm{mM}\left(\mathrm{NH}_{4}\right)_{2} \mathrm{SO}_{4}, 1.5 \mathrm{mM} \mathrm{MgCl}_{2}$, using $12 \mathrm{ng}$ of each primer, $70 \mu \mathrm{M}$ of each dNTP, and $1 \mu \mathrm{Ci}$ of $\left[\alpha^{-}{ }^{33} \mathrm{P}\right] \mathrm{dATP}(3000 \mathrm{Ci} / \mathrm{mmol}$; Du Pont Co., Boston, MA) in a total volume of $10 \mu \mathrm{l}$. After initial denaturation at $96^{\circ} \mathrm{C}$ for $4 \mathrm{~min}, 0.3 \mathrm{U}$ of Hot Tub polymerase (Amersham, Arlington Heights, IL) was added at $80^{\circ} \mathrm{C}$, and 30 cycles of PCR were performed $\left(96^{\circ} \mathrm{C}\right.$ for $30 \mathrm{~s}, 57^{\circ} \mathrm{C}$ for $30 \mathrm{~s}, 72^{\circ} \mathrm{C}$ for $\left.120 \mathrm{~s}\right)$.

$5 \mu \mathrm{l}$ of each sample was digested with either PstI or EcoRI in a volume of $10 \mu \mathrm{l} .1 \mu \mathrm{l}$ of $1 \%$ SDS-containing $100 \mathrm{mM}$ EDTA was added followed by $11 \mu \mathrm{l}$ of loading buffer containing $95 \%$ formamide $10 \mathrm{mM} \mathrm{NaOH}, 0.05 \%$ bromophenol blue and $0.05 \%$ xylene cyanol.
After denaturation at $96^{\circ} \mathrm{C}$ for $2 \mathrm{~min}$, the samples were quenched on ice, and $2 \mu \mathrm{l}$ of each was loaded onto a $4 \%$ nondenaturing polyacrylamide gel $(50 \times 35 \mathrm{~cm}$ and $0.4 \mathrm{~mm}$ thick $)$ containing $10 \%$ glycerol ( vol/vol) and $0.5 \times$ TBE (45 mM Tris-borate, $1 \mathrm{mM}$ EDTA) using a sequencing apparatus (Bio-Rad, Richmond, CA). The gel was electrophoresed in a cold room, with a fan for extra cooling, at a constant power of $100 \mathrm{~W}$ for $5 \mathrm{~h}$. By these means, the temperature of the upper buffer chamber was kept at a constant $15^{\circ} \mathrm{C}$. After fixing for $45 \mathrm{~min}$ using $10 \%$ methanol, $10 \%$ acetic acid, the gel was dried and autoradiographed for $18 \mathrm{~h}$.

Screening for the Arg ${ }_{3531} \rightarrow$ Cys and $\mathrm{Arg}_{3500} \rightarrow$ Gln mutations. The $\operatorname{Arg}_{3531} \rightarrow$ Cys mutation introduces a new NsiI site at nucleotide 10799 This enabled screening for the mutation among 1,560 DNA samples. These were obtained from 1,368 subjects attending the Lipid Clinic and 192 normolipidemic controls. A 1582-bp region of apoB exon 26 (nucleotides 9561-11142) was amplified by PCR using primers 20 and 41 (Table I) and the same conditions as previously described. This fragment contains an NsiI site at nucleotide 9769 , which served as a control. After digestion with Nsil, samples were run on a $1.5 \%$ agarose gel containing ethidium bromide.

The same PCR products were screened for the $\operatorname{Arg}_{3500} \rightarrow$ Gln mutation using a differential hybridization assay. A dot blot hybridization procedure was set up as described by Soria et al. (5), except that nonradioactively labeled allele-specific oligonucleotides (ASOs) and chemiluminescent detection were used. Plasmids containing the mutant or normal sequence (p43 and p469, respectively; a gift from Dr. Steve Russell, Gladstone Research Laboratories, San Francisco, CA) were used as controls. The DNA was transferred to a nylon membrane (Schleicher \& Schuell, Keene, NH) using a dot blotter (Minifold II, Schleicher \& Schuell), fixed by ultraviolet irradiation, and hybridized with the mutant ASO $(50 \mathrm{ng} / \mu \mathrm{l})(5)$ that had been tailed with digoxigenin-11-dUTP using terminal transferase (Boehringer Mannheim, Indianapolis, IN). The hybridization was performed in $5 \times \operatorname{SSPE}(0.15 \mathrm{M} \mathrm{NaCl}, 10 \mathrm{mM}$ $\mathrm{NaH}_{2} \mathrm{PO}_{4}, 1$ mM EDTA, pH 7.4), $5 \times$ Denhardt's solution (28), $0.5 \%$ $\mathrm{SDS}$ at $23^{\circ} \mathrm{C}$ for $2 \mathrm{~h}$. After incubation with anti-digoxigenin alkaline phosphatase conjugate and then with Lumi-Phos 530 (Boehringer Mannheim), the membrane was exposed to X-Omat RP film (Eastman Kodak, Rochester, NY). The filter was stripped of the mutant ASO in the presence of $\mathrm{NaOH}(0.2 \mathrm{M})$ and $\mathrm{SDS}(0.1 \%)$ at $37^{\circ} \mathrm{C}$ and reprobed with the control ASO (5).

Fibroblast $L D L$ receptor binding assay. A dual-label equilibrium binding assay, recently developed by one of us (C. M. Mendel) (23), was used to determine the effect of the apoB $\mathrm{Arg}_{3531} \rightarrow$ Cys mutation the on binding of LDL to the LDL receptor. This technique compares, quantitatively, the equilibrium association constant of the sample LDL with that of a reference LDL. Extensive validation of this technique, along with a detailed description, has been provided elsewhere (23). An abbreviated description follows.

LDL $(1.019<d<1.063 \mathrm{~g} / \mathrm{ml})$ was prepared by sequential ultracentrifugation as previously described (23) from the 8 individuals with the mutation, from 8 nonaffected family members, from 6 subjects with the $\operatorname{Arg}_{3500} \rightarrow$ Gln mutation, and from 11 normolipidemic laboratory personnel. $\mathrm{KBr}$ was used to adjust the solvent densities. The LDL samples were dialyzed against $\mathrm{NaCl}(0.9 \%)$, EDTA $(0.04 \%)$, and sodium azide $(0.05 \%)$ and stored at $4^{\circ} \mathrm{C}$. Reference LDL, prepared from a fasting normal subject, was stored in $20 \%$ sucrose in individual aliquots at $-70^{\circ} \mathrm{C}$, as previously described $(23)$.

Sample LDL and reference LDL were labeled $(0.5 \mathrm{mCi}$ per $\mathrm{mg}$ of LDL) with ${ }^{125}$ I and ${ }^{131} I$, respectively, by the iodine monochloride method as modified for lipoproteins (29), extensively dialyzed as previously described, and stored at $4^{\circ} \mathrm{C}$; the binding assay was performed within $3 \mathrm{~d}$ of the iodination. Human newborn foreskin fibroblasts (10th-18th passage) were used in the binding assay. They were grown under $8 \%$ $\mathrm{CO}_{2}$ in 35-mm dishes in $\mathrm{H} 21$ DME supplemented with glutamine (2 $\mathrm{mM})$, gentamicin $(50 \mu \mathrm{g} / \mathrm{ml})$, and FCS (10\%). At 80-90\% confluency and $48 \mathrm{~h}$ before the assay, the medium was replaced with DME con- 


\begin{tabular}{|c|c|c|c|c|}
\hline Gene & PCR primers for & $\begin{array}{l}\text { Primer } \\
\text { number }\end{array}$ & Sequence & Site \\
\hline \multirow[t]{12}{*}{ apoB } & \multirow[t]{2}{*}{ SSCP analysis } & 94 & 5'-TACCAAGTCAAAACCTACTGTCTCTTCC-3' & $10469-10496$ (cDNA), sense \\
\hline & & 88 & 5'-GCgAaTTCCTGGCCAAGGTCAGGGAAATC-3' & $10962-10990$ (cDNA), antisense \\
\hline & \multirow[t]{2}{*}{$3500 / 3531$ screening } & 20 & 5'-CСТCCACTGAAAGATTTCTCTCTATGGG-3' & $9561-9588$ (cDNA), sense \\
\hline & & 41 & 5'-GGAAgCTTAGGTGTCCTTCTAAGGATCCTG-3' & 11113-11142 (cDNA), antisense \\
\hline & \multirow[t]{2}{*}{ ApaLI RFLP (exon 4) } & 128 & 5'-CCATGCCTAGGGGCAAACTTAAGAAATGTGTTACC-3' & Intron 3, sense \\
\hline & & 129 & 5'-GGACACACACgCATGCGTGTGCTCATGTACAAC-3' & Intron 4, antisense \\
\hline & \multirow[t]{2}{*}{ AluI RFLP (exon 14) } & 146 & 5'-GAGTCAAAGGATAATAACATGGTGTGTCAGCTC-3' & Intron 13 , sense \\
\hline & & 131 & 5'-GGCTCCCgGGGACTCTCTGTTTATGATGCTG-3' & Intron 14 , antisense \\
\hline & \multirow{2}{*}{ BfaI RFLP (exon 26) } & 152 & 5'-ACAGTGAGCTGCAGTGGCCCGTTCCAG-3' & 8170-8196 (cDNA), sense \\
\hline & & 30 & 5'-GCTATGTGGCaAGCTTTCAACAGTGTC-3' & $8861-8887$ (cDNA), antisense \\
\hline & \multirow[t]{2}{*}{ Eco57I RFLP (exon 29) } & 154 & 5'-AAGCCATTCAGTCTCTCAAGACCACAGAGG-3' & $12982-13011$ (cDNA), sense \\
\hline & & 155 & 5'-ATGGATCTGCTGTAACTCTTGAGAAGCTTCC-3' & $13232-13262$ (cDNA), antisense \\
\hline \multirow[t]{8}{*}{ LDL receptor } & \multirow[t]{2}{*}{ BsmAI RFLP (exon 10) } & 167 & 5'-ATGCCCTTCTCTCCTCCTGCCTCAGCAC-3' & Intron 9, sense \\
\hline & & 168 & 5'-AGCCCTCAGCGTCGTGGATACGCACCCA-3' & Intron 10 , antisense \\
\hline & \multirow[t]{2}{*}{ HincII RFLP (exon 12) } & 138 & 5'-TCTCCTTATCCACTTGTGTGTCTAGATCTC-3' & Intron 11 , sense \\
\hline & & 139 & 5'-CTTCGATCTCGTACGTAAGCCACACCTC-3' & Intron 12 , antisense \\
\hline & \multirow[t]{2}{*}{ HaeIII RFLP (exon 18) } & 140 & 5'-TCCGCTGTTTACCATTTGTTGGCAGAGAC-3' & Intron 17 , sense \\
\hline & & 141 & 5'-CACGGTGGAGAGAAACTCAAAACTTCCTGG-3' & $2836-2865$ (cDNA), antisense \\
\hline & \multirow[t]{2}{*}{ NcoI RFLP (exon 18) } & 165 & 5'-TGCTTCCACTTCTATGCAAATGCCTCCAAG-3' & $3615-3644$ (cDNA), sense \\
\hline & & 166 & 5'-TAACACGGCGATTTCAGAAAGAACCTGAAG-3' & 4523-4552 (cDNA), antisense \\
\hline
\end{tabular}

Nucleotides in lowercase letters indicate the changes that were made in order to incorporate restriction sites.

taining lipoprotein-deficient serum (10\%) and lovastatin $(1 \mu \mathrm{g} / \mathrm{ml}$; Merck \& Co., West Point, PA).

After the fibroblasts had been washed twice with Dulbecco's PBS, the ${ }^{125} \mathrm{I}-$ and ${ }^{131} \mathrm{I}-\mathrm{LDL}(0.5 \mu \mathrm{g} / \mathrm{ml}$ protein each $)$ plus HSA $(0.2 \%)$ and Hepes ( $25 \mathrm{mM}, \mathrm{pH} 7.4)$ in DME were added. After a 3-h incubation at $4^{\circ} \mathrm{C}$, maximum binding was achieved. The radioactivity in the unbound LDL ( ${ }^{125} \mathrm{I}$ and ${ }^{131} \mathrm{I}$ labeled) was measured in an aliquot of the medium using an automated gamma counter. After four washings at $4^{\circ} \mathrm{C}$ with PBS containing BSA $(0.4 \%)$ and one washing with PBS alone, the cells were dissolved in $\mathrm{NaOH}(0.1 \mathrm{M})$, and their radioactive content (bound LDL) was determined. Nonspecific binding, defined as radiolabeled LDL bound in the presence of $200 \mu \mathrm{g} / \mathrm{ml}$ unlabeled LDL, was usually $<5 \%$ of the total binding.

If the ratio of bound to free ${ }^{131} \mathrm{I}-\mathrm{LDL}$ is defined as $\mathrm{R} 1$ and that of ${ }^{125} \mathrm{I}-\mathrm{LDL}$ as R2, it can be shown that under the experimental conditions described, $R 1 / R 2$ is equal to $K 1 / K 2$, where $K 1$ and $K 2$ are the equilibrium association constants of the reference LDL $\left({ }^{131} \mathrm{I}-\mathrm{LDL}\right)$ and the sample LDL $\left({ }^{25} \mathrm{I}-\mathrm{LDL}\right)$, respectively, for the LDL receptor (23). Values of R1/R2 > 1 mean that the sample LDL has a lower affinity for the receptor than the reference LDL.

Measurement of mass ratios of apoB allele products. To measure the mass ratios of the two apoB allelic products, mAb MB19, which recognizes the $\mathrm{Ag}(\mathrm{c} / \mathrm{g})$ polymorphism (ApaLI RFLP) of apoB $(30,31)$ was used. LDL $(1.021<d<1.055 \mathrm{~g} / \mathrm{ml})$ were isolated as previously described from the plasma of three individuals who possessed the $\operatorname{Arg}_{3531} \rightarrow$ Cys mutation and who were also heterozygous for the ApaLI RFLP (Thr/Ile polymorphism at residue 71) (32). Samples were diluted to a protein concentration of $1.5 \times 10^{-8} \mathrm{M}$ in $0.195 \mathrm{M} \mathrm{NaCl}, 0.04 \%$ EDTA, and $0.05 \% \mathrm{NaN}_{3}$. Particle diameters were determined on 1-ml aliquots in quartz cuvettes at $23^{\circ} \mathrm{C}$, by dynamic light scattering, using a particle sizer (Nicomp model 270, Particle Sizing Systems, Santa Barbara, CA). An equivalent amount of MB19 was added, and the particle diameters were remeasured. The sharp increase in the diameter that was observed was principally due to the dimerization of the $\mathrm{Ile}_{71}$ LDL, which has a much higher binding affinity than the $\mathrm{Thr}_{71}$ particles. A control experiment was run on each sample using mAb MB47, which caused dimerization of virtually all of the particles, in order to determine the maximum increase. The percentage of high affinity particles in each sample was then determined from a calibration curve, constructed from artificial mixtures of high and low affinity LDL isolated from Ile/lle $[\mathrm{Ag}(\mathrm{c} / \mathrm{c})]$ and $\mathrm{Thr} / \mathrm{Thr}[\mathrm{Ag}(\mathrm{g} / \mathrm{g})]$ homozygotes, respectively.

$a p o B$ gene haplotyping. $10 a p o B$ gene polymorphic markers were analyzed by PCR. Except when noted, the PCR conditions were as previously described. We have previously reported the primers and conditions used for assaying the XbaI, MspI, and EcoRI RFLPs and the 3' hypervariable region (HVR) (25). In the present study, the $3^{\prime}$ HVR primers were end labeled with $\left[\gamma-{ }^{32} \mathrm{P}\right]$ ATP (Du Pont Co.) and the PCR products were electrophoresed on $6 \%$ polyacrylamide gels. The 5' (TG)n polymorphism was assayed as described by Ludwig and McCarthy (33). Primers 128 and $129\left(58^{\circ} \mathrm{C}\right.$ annealing, $3 \mathrm{mM} \mathrm{MgCl}$ ) were used for the ApaLI RFLP (nucleotide 421) (32), and primers 131 and $146\left(60^{\circ} \mathrm{C}\right.$ annealing) were used for the AluI RFLP (nucleotide 1981) (34).

BfaI was used to detect the polymorphism at nucleotide 8344 (residue 2712) (35). Primers 30 and 152 were used with an annealing temperature of $60^{\circ} \mathrm{C}$. The polymorphism at nucleotide 13141 (residue 4311 ) (36) was detected using primers 154 and 155 and the enzyme Eco57I.

$L D L$ receptor genetic markers. Five LDL receptor gene markers were studied, using PCR, in the two kindreds with the $\operatorname{Arg}_{3531} \rightarrow$ Cys mutation. The PCR primers are listed in Table I. The polymorphism in exon 10 at nucleotide 1413 (37) was assayed using BsmAI. Three other RFLPs were studied: the HincII RFLP at cDNA nucleotide 1768 (38), the HaeIII RFLP at nucleotide 2635 (39), and the Ncol polymorphism in the $3^{\prime}$ untranslated region (40). The digested PCR products were examined on agarose gels. The dinucleotide repeat polymorphism at the $3^{\prime}$ end of the gene was analyzed as reported by Zuliani and Hobbs (41), except that the PCR conditions were as previously described, with an annealing temperature of $54^{\circ} \mathrm{C}$.

apoE genotyping and phenotyping. The method described by Hixon and Vernier (42) was followed to ascertain the apoE genotypes. When possible, phenotypes were determined by isoelectric focusing of apoVLDL as previously described $(26,43)$.

\section{Results}

Discovery of $\mathrm{Arg}_{3531} \rightarrow$ Cys mutation by SSCP analysis. Electrophoresis of a PstI digest of an amplified region of exon 26 


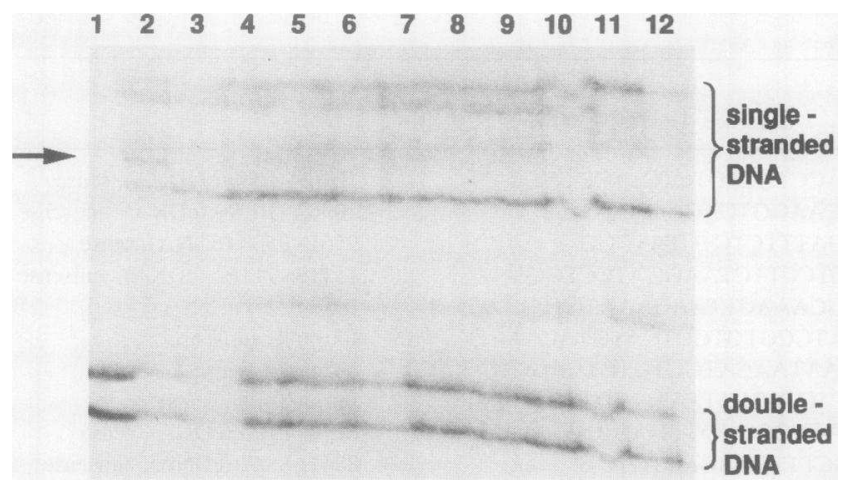

Figure 1. SSCP analysis of ${ }^{33} \mathrm{P}$-labeled DNA (apoB nucleotides $10469-$ 10990) amplified from 11 hypercholesterolemic subjects. The DNA was digested with PstI before loading onto a $4 \%$ polyacrylamide strandseparating gel containing $10 \%$ glycerol. The gel was run at $15^{\circ} \mathrm{C}$ and $100 \mathrm{~W}$ for $5 \mathrm{~h}$. Lane 1 , undenatured control DNA. Lanes 2-11, denatured samples; lane 2, DNA amplified from the proband in the L.S. kindred (I-6), showing a mobility shift.

(nucleotides 10469-10990) on a strand-separating gel showed an abnormal pattern in the case of one patient (Fig. 1, lane 2). An EcoRI digest of material from this individual also showed a mobility shift (Fig. 2, lane 1), which was different from that seen in patients with the mutation at nucleotide 10708 $\left(\operatorname{Arg}_{3500} \rightarrow \mathrm{Gln}\right)$. To the best of our knowledge, no polymorphisms have been reported for this region. Dideoxy sequencing was performed on single-stranded DNA produced by asymmetric PCR of the patient's DNA and control DNA, using primers 41 and 94 . The only difference between the patient's and the normal sequence was a single nucleotide substitution at position 10800 in codon 3531 (Fig. 3). This changes the arginine codon CGC to cysteine, TGC. When screened for the presence of the novel NsiI site, which is introduced at nucleotide 10799 as a result of the 3531 mutation, genomic DNA samples from relatives of this patient revealed a total of six individuals with the mutation (Fig. 4). In addition, 1,368 individuals attending the Lipid Clinic and 192 normolipidemic controls were screened for this mutation and for the 3500 mutation. One additional patient (unrelated to the first) was found with the 3531 mutation, and a total of 12 unrelated subjects were found with the 3500 mutation. Analysis of DNA from relatives of the second proband revealed one additional individual (his brother) with the 3531 mutation. Hence, in the two kindreds, a total of eight individuals were found with the 3531 mutation (Fig. 5). The L.S. kindred is of Celtic and Native American origin, and the A.C. kindred is of Italian origin.

Lipid profiles of two kindreds. Hypercholesterolemia and a history of atherosclerosis are present in both kindreds (Table II). Of the 16 individuals studied, 9 have serum levels of LDL cholesterol above the 90 th or 95 th percentiles. As can be seen (Fig. 5), there is no simple cosegregation of the hypercholesterolemia, in either kindred, with the 3531 mutation. However, for the eight subjects heterozygous for the 3531 mutation, the mean adjusted values for both total serum cholesterol and LDL cholesterol (Table III) are significantly higher than the corresponding values from the eight family members lacking the mutation $(P \leq 0.02)$. They are also significantly higher than those for control subjects $(P \leq 0.001)$, whereas the values from the eight

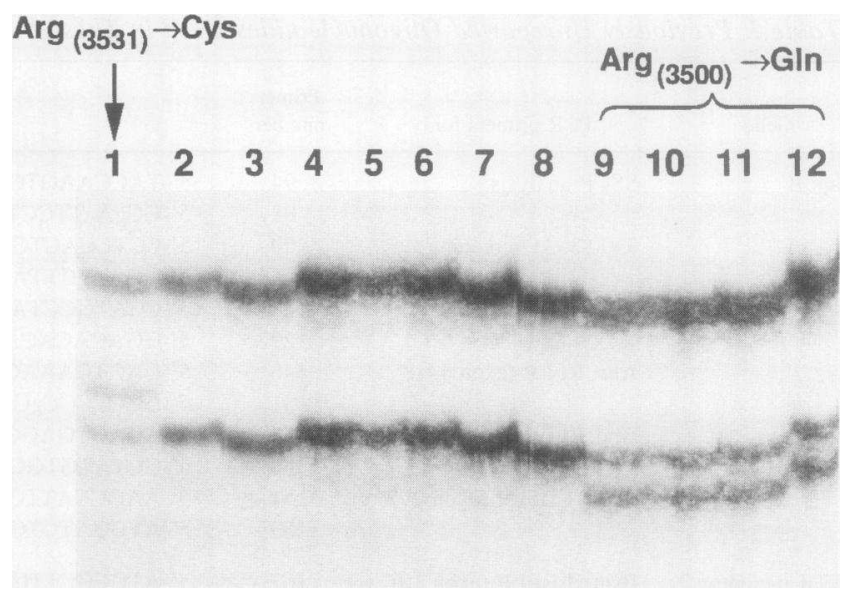

Figure 2. SSCP analysis of DNA (apoB nucleotides 10469-10990) amplified from the proband of the L.S. kindred (lane 1 ) and 11 other hypercholesterolemic subjects, including 4 with the $\operatorname{Arg}_{3500} \rightarrow$ Gln mutation (lanes 9-12). The DNA was digested with EcoRI before loading onto a $4 \%$ polyacrylamide strand-separating gel containing $10 \%$ glycerol. The gel was run at $15^{\circ} \mathrm{C}$ and $100 \mathrm{~W}$ for $5 \mathrm{~h}$. Lanes 1 and 9-12 show opposite mobility shifts of the same fragment.

unaffected members are not different from values for controls. When adjusted for age and sex, total cholesterol and LDL cholesterol in the eight 3531 individuals were higher by 70 and 66 $\mathrm{mg} / \mathrm{dl}$, respectively, than those of controls. The corresponding values for six patients with the 3500 mutation were 95 and 95 $\mathrm{mg} / \mathrm{dl}$, respectively.

$L D L$ receptor haplotyping. Hypercholesterolemia in patients with the 3531 mutation could be coincidental and could be due to a defect in the LDL receptor gene, despite the observed association between elevated lipid values and the presence of the 3531 mutation. LDL receptor gene haplotypes are shown in Fig. 5. As with the 3531 mutation, there is no simple cosegregation of the $\mathrm{LDL}$ receptor gene in these two kindreds with serum levels of cholesterol.

In the L.S. kindred (Fig. 5), subjects II-4 and II-5 have inherited different LDL receptor alleles from their mothers (subject I-6, the proband in this kindred). Only II-5 has the elevated lipid levels seen in her mother. She also has the 3531 apoB mutation. This does not therefore discriminate between FH or the 3531 mutation as potential causes of the hyperlipidemia seen in subjects I-6 and II-5. However, observations in the family of the proband's sister (subject I-4) are informative in this respect (Fig. 5). This woman has different LDL receptor haplotypes ( $b$ and $e$ ) from those (a and $f$ ) carried by subject I-6 (the proband) and also has an adjusted level of LDL cholesterol above the 95th percentile. Her offspring, II-1, II-2, and II-3, all inherited the same LDL receptor allele (haplotype b), as well as the apoB 3531 mutation, from their mother. However, although subjects II-1 and II-2 have levels of LDL cholesterol above the 95th and 90th percentiles, respectively, subject II-3 has a value in the normal range.

In the A.C. kindred, the proband (I-3) has an adjusted level of LDL cholesterol above the 95th percentile (Fig. 5). His daughter (II-2) has inherited from her father an LDL receptor different from that inherited by her brother (II-1). Like her 


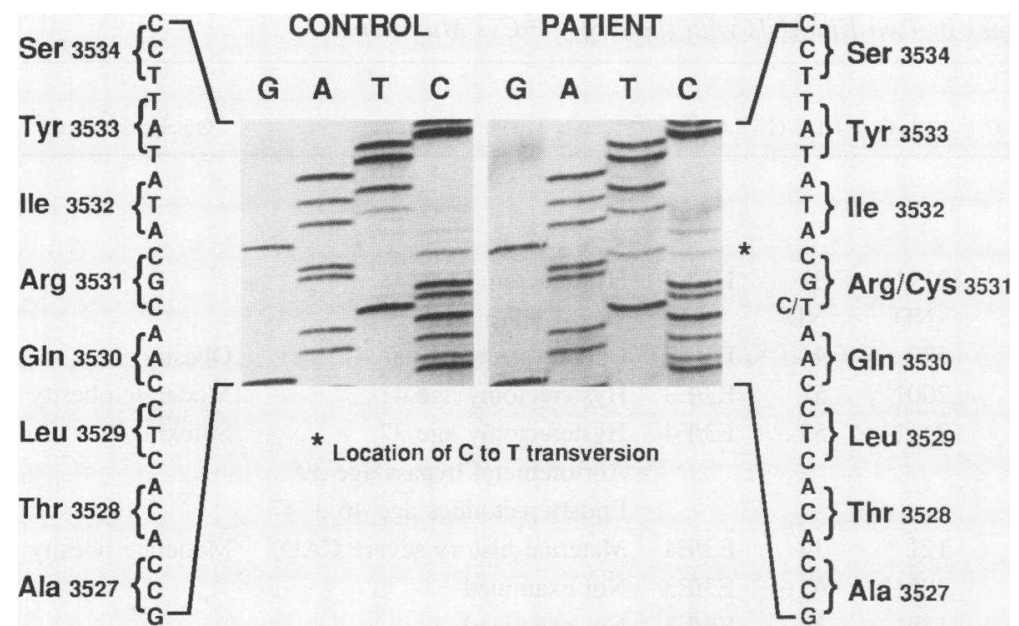

Figure 3. DNA sequencing gel showing the single nucleotide change leading to the $\operatorname{Arg}_{3531} \rightarrow$ Cys substitution. The ladders show part of exon 26 of the apoB gene. An asterisk indicates the $\mathrm{T}$ for $\mathrm{C}$ substitution in codon 3531 . Single-stranded DNA prepared by asymmetric PCR using primers 41 and 94 was directly sequenced with Sequenase (United States Biochemical Corp., Cleveland, $\mathrm{OH}$ ) using primer 44. brother, she has a moderately elevated level of LDL cholesterol, with her value being above the 90th percentile.

Equilibrium binding studies. The results of the fibroblast binding experiments (Table III) indicate that the equilibrium association constant of the LDL prepared from subjects heterozygous for the 3531 mutation was $60.3 \pm 3.4 \%$ that of the reference LDL. This value was significantly different from that obtained with LDL from 11 normolipidemic control subjects $(P$ $\leq 0.001$ ) or from the 8 individuals in the two kindreds who did not carry the mutation $(P=0.004)$. By way of comparison, a value of $34.3 \pm 3.0 \%$ was found for LDL prepared from six patients who were heterozygous for the 3500 mutation ( $P$ $\leq 0.001$ versus controls). The binding affinity of the LDL obtained from the eight unaffected members of the two kindreds was $87.3 \pm 7.1 \%$ that of the reference LDL, which was not significantly different from control LDL, which had $95.9 \pm 5.4 \%$ of the reference affinity.

The mean binding affinity of the LDL prepared from the eight subjects with the 3531 mutation was $62.9 \%$ of the mean control value, that from the eight unrelated family members was $91.0 \%$, and that of the six subjects with the 3500 mutation was $35.8 \%$. (See the following section for the calculation of the binding affinity of the defective LDL particles.)

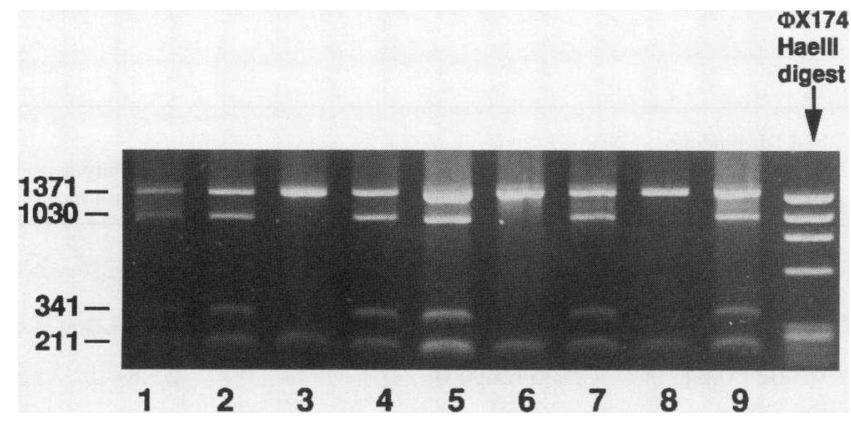

Figure 4. An agarose gel showing the six individuals in the L. S. kindred with the apoB 3531 mutation: lanes 1 (II-3), 2 (I-4), 4 (II-2), 5 (II1 ), 7 (II-5), and 9 (I-6). The gel shows three individuals that are unaffected: lanes 3 (I-3), 6 (I-1), and 8 (II-4). DNA (nucleotides $9561-11142$ ) amplified using primers 20 and 41 from genomic DNA was digested with NsiI.
Mass ratios of apoB allele products. The ratio of apoB $\mathrm{Cys}_{3531}$ LDL particles to those with normal apoB $\mathrm{Arg}_{3531}$ was determined for three individuals heterozygous for the $\mathrm{Arg}_{3531} \rightarrow$ Cys mutation who were also heterozygous for the Thr/ Ile polymorphism at amino acid residue 71 by a novel unpub-

\section{L.S. Kindred}

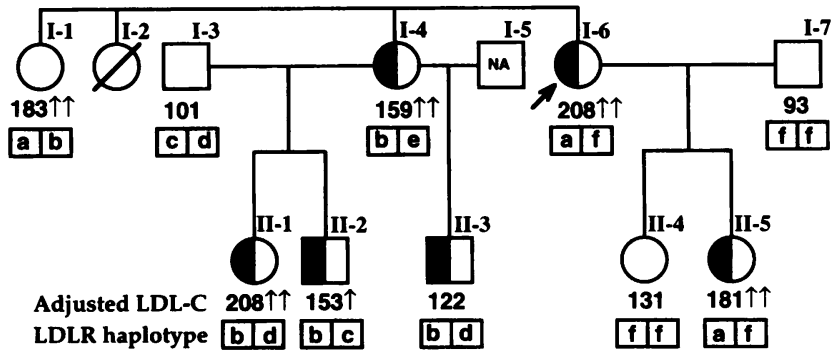

A.C. Kindred
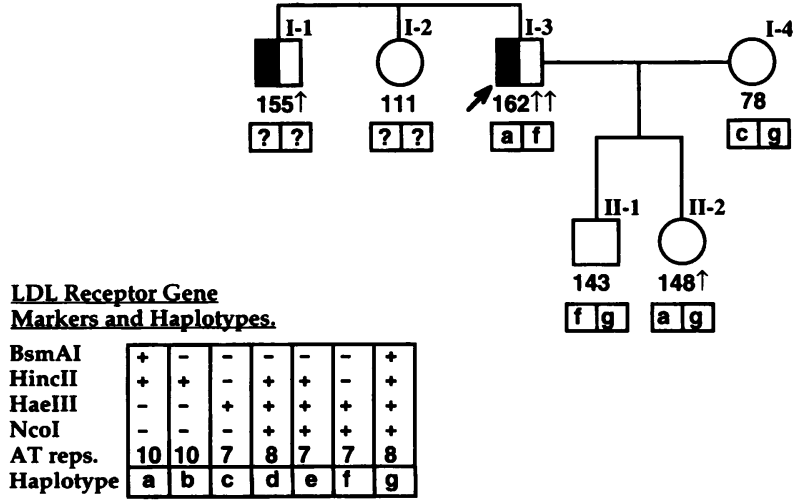

Figure 5. Pedigrees of the two kindreds studied. $D$ and $\Phi$ indicate males and females, respectively, heterozygous for the presence of the apoB $\operatorname{Arg}_{3531} \rightarrow$ Cys mutation. Beneath the symbols are levels of LDL cholesterol (in milligrams per deciliter), adjusted for age and gender. Values above the 95th percentile are marked $\pi$, and those above the 90th percentile marked $\uparrow$. Also shown are LDL receptor gene haplotypes. For clarity, only those individuals available for study are shown, with the exception of I-2 and II-5 in the L.S. kindred. 
Table II. Unadjusted Serum Lipid Values and apoE Genotypes in Two Kindreds with the Arg ${ }_{3531} \rightarrow$ Cys Mutation

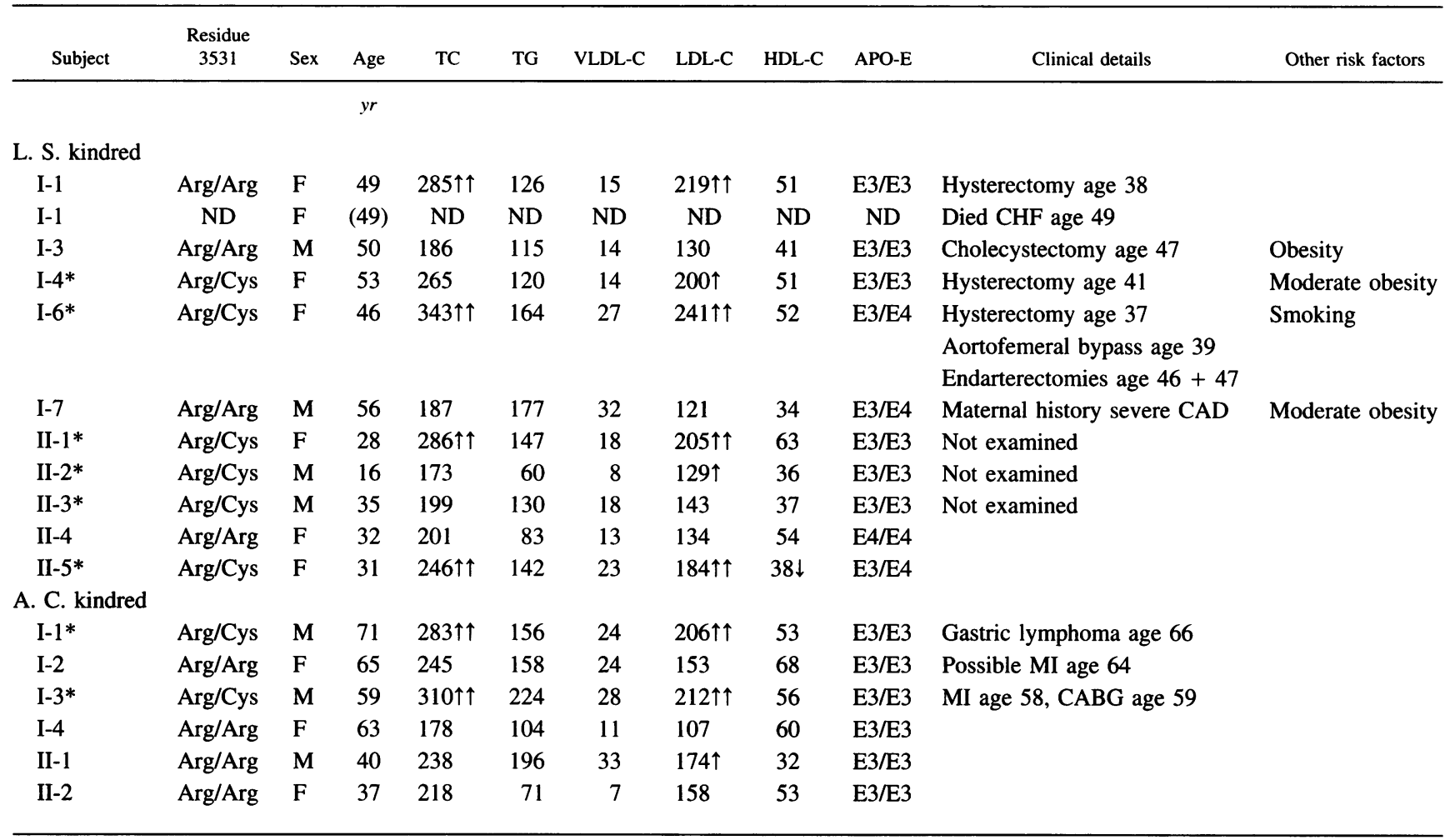

Lipid values are all in milligrams per deciliter. Those values above the 90th or 95th percentile are marked $\uparrow$ and $\uparrow \uparrow$, respectively, and those below the 10th percentile are marked $\downarrow$ (age and sex matched with the Lipid Research Clinics' Population Studies Data Book). * Subjects heterozygous for the $\mathrm{Arg}_{3531} \rightarrow$ Cys mutation. TC, total cholesterol; TG, triglycerides; C, cholesterol content; ND, not determined.

lished method developed by two of us (J. E. Chatterton and V. N. Schumaker). Briefly, mAb MB19 recognized the Thr/Ile polymorphism by binding with higher affinity when Ile was present at residue 71 than when Thr was present (30). When an equivalent amount of MB19 was added to LDL from an Ile/ Ile homozygote at an apoB concentration of $1.5 \times 10^{-8} \mathrm{M}$, most of the LDL particles were cross-linked by antibody to form an LDL dimer, as determined by measuring the increase in particle diameter by dynamic light scattering. In contrast, when the same amount of MB19 was added to LDL from a
Thr/Thr homozygote, most of the LDL particles remained as monomers. When added to LDL from an Thr/Ile heterozygote, an intermediate amount of LDL dimerization occurred. As a control, measurements were also made with mAb MB47, which caused a maximal diameter increase with Ile/Ile LDL or Thr/ Thr LDL. With sample LDL, the ratio of the two forms of apoB and of the LDL on which they resided were then determined by comparison with a calibration curve constructed from mixtures of Ile/Ile LDL and Thr/Thr LDL at known ratios. The error in this technique was estimated to be $< \pm 2 \%$.

Table III. LDL Receptor Binding and Serum Cholesterol Analysis

\begin{tabular}{|c|c|c|c|c|c|c|}
\hline & $n$ & $\begin{array}{c}\text { Total } \\
\text { cholesterol }\end{array}$ & $\begin{array}{c}\text { LDL } \\
\text { cholesterol }\end{array}$ & $\begin{array}{l}\text { LDL binding } \\
\text { coefficient: } \\
\text { R1/R2 }\end{array}$ & $\begin{array}{l}\text { LDL binding affinity as a } \\
\text { percentage of reference LDL }\end{array}$ & $\begin{array}{l}\text { LDL binding affinity as a } \\
\text { percentage of control mean* }\end{array}$ \\
\hline Controls & 11 & $170 \pm 11$ & $103 \pm 9$ & $1.07 \pm 0.05$ & $95.9 \pm 5.4$ & 100 \\
\hline $3531 \mathrm{Arg} / \mathrm{Cys}$ & 8 & $240 \pm 14^{\ddagger \S}$ & $169 \pm 10^{\ddagger 8}$ & $1.69 \pm 0.09^{\ddagger \|}$ & $60.3 \pm 3.4^{\ddagger \|}$ & 62.9 \\
\hline $3531 \mathrm{Arg} / \mathrm{Arg}$ (unaffected family members) & 8 & $185 \pm 12$ & $124 \pm 12$ & $1.20 \pm 0.11$ & $87.3 \pm 7.1$ & 91.0 \\
\hline $3500 \mathrm{Arg} / \mathrm{Gln}$ & 6 & $265 \pm 35^{1}$ & $198 \pm 30^{1}$ & $3.02 \pm 0.24^{\ddagger}$ & $34.3 \pm 3.0^{\ddagger}$ & 35.8 \\
\hline
\end{tabular}

Cholesterol values are in milligrams per deciliter and have been adjusted for age and sex. $\mathrm{R} 1 / \mathrm{R} 2=\mathrm{K} 1 / \mathrm{K} 2$, where $\mathrm{K} 1$ is the equilibrium association constant of a reference LDL, and $\mathrm{K} 2$ is that of the sample LDL (values $>1.0$ indicate that the sample LDL has a lower affinity than the reference LDL). * To compare the binding affinity of LDL from the three experimental groups with the mean value obtained from LDL prepared from the 11 control subjects, we set this latter value to $100 \%$. All values are the mean \pm SEM. ${ }^{\ddagger}$ Statistically different from controls, $P \leq 0.001$ (unpaired $t$ test). ${ }^{8}$ Statistically different from unaffected family members, $P \leq 0.02$. "Statistically different from unaffected family members, $P=0.004$.

"Statistically different from controls, $P=0.005$. 
Table IV. apoB Genetic Markers in Two Kindreds with the Arg ${ }_{3531} \rightarrow$ Cys Mutation

\begin{tabular}{|c|c|c|c|c|c|c|c|c|c|c|c|c|}
\hline Subject & Haplotype & $5^{\prime}(\mathrm{TG}) \mathrm{n}$ & Ins/Del & ApaLI & AluI & XbaI & Bfal & $\operatorname{Arg}_{3531} \rightarrow$ Cys & MspI & EcoRI & Eco57I & 3' HVR \\
\hline \multicolumn{13}{|c|}{ L. S. kindred } \\
\hline I-1 & $\mathrm{A} / \mathrm{B}$ & $14 / 14$ & I/I & $+/+$ & $+1+$ & $+1-$ & $-1-$ & $-1-$ & $+1+$ & $+/+$ & $-1-$ & $36 / 42$ \\
\hline $\mathrm{I}-3$ & $\mathrm{C} / \mathrm{D}$ & $14 / 15$ & $\mathrm{I} / \mathrm{I}$ & $+1+$ & $-1-$ & $-1-$ & $+1-$ & $-1-$ & $+/+$ & $+1-$ & $+1-$ & $34 / 46$ \\
\hline I-4* & $\mathrm{E} / \mathrm{F}$ & $14 / 14$ & $\mathrm{I} / \mathrm{D}$ & $+1-$ & $+1-$ & $+1+$ & $-1-$ & $+1-$ & $+/+$ & $+/+$ & $-1-$ & $34 / 38$ \\
\hline I-6* & $\mathrm{E} / \mathrm{B}$ & $14 / 14$ & $\mathbf{I} / \mathbf{I}$ & $+1+$ & $+1-$ & $+1-$ & $-1-$ & $+1-$ & $+1+$ & $+/+$ & $-1-$ & $34 / 42$ \\
\hline $\mathrm{I}-7$ & $\mathrm{G} / \mathrm{H}$ & $14 / 14$ & $\mathbf{I} / \mathbf{I}$ & $+/+$ & $-1-$ & $+1-$ & $-1-$ & $-1-$ & $+1+$ & $+1-$ & $-1-$ & $36 / 48$ \\
\hline II-1* & $\mathrm{E} / \mathrm{C}$ & $14 / 14$ & $\mathbf{I} / \mathbf{I}$ & $+/+$ & $-1-$ & $+1-$ & $+1-$ & $+1-$ & $+1+$ & $+1+$ & $+1-$ & $34 / 34$ \\
\hline II-2* & $\mathrm{E} / \mathrm{C}$ & $14 / 14$ & $\mathbf{I} / \mathbf{I}$ & $+1+$ & $-1-$ & $+1-$ & $+1-$ & $+1-$ & $+1+$ & $+1+$ & $+1-$ & $34 / 34$ \\
\hline II-3* & $\mathrm{E} / \mathrm{I}$ & $14 / 14$ & $\mathrm{I} / \mathrm{D}$ & $+1-$ & $+1-$ & $+1+$ & $-1-$ & $+1-$ & $+1+$ & $+/+$ & $-1-$ & $34 / 40$ \\
\hline II-4 & $\mathrm{B} / \mathrm{H}$ & $14 / 14$ & $\mathrm{I} / \mathrm{I}$ & $+/+$ & $+1-$ & $-1-$ & $-1-$ & $-1-$ & $+1+$ & $+1-$ & $-1-$ & $42 / 48$ \\
\hline II-5* & $\mathrm{E} / \mathrm{H}$ & $14 / 14$ & $\mathbf{I} / \mathbf{I}$ & $+1+$ & $-1-$ & $+1-$ & $-1-$ & $+1-$ & $+1+$ & $+1-$ & $-1-$ & $34 / 48$ \\
\hline \multicolumn{13}{|c|}{ A. C. kindred } \\
\hline $\mathrm{I}-1^{*}$ & $\mathrm{~J} / \mathrm{K}$ & $14 / 14$ & I/D & $+1-$ & $+1-$ & $+1-$ & $+1-$ & $+1-$ & $+1+$ & $+/+$ & $+1-$ & $34 / 36$ \\
\hline $\mathrm{I}-2$ & $? / ?$ & $14 / 15$ & $\mathrm{D} / \mathrm{D}$ & $-1-$ & $+1+$ & $+1-$ & $-1-$ & $-1-$ & $+1+$ & $+/+$ & $-1-$ & $34 / 36$ \\
\hline I-3* & $\mathrm{J} / \mathrm{K}$ & $14 / 14$ & I/D & $+1-$ & $+1-$ & $+1-$ & $+1-$ & $+1-$ & $+1+$ & $+/+$ & $+1-$ & $34 / 36$ \\
\hline $\mathrm{I}-4$ & $\mathrm{~L} / \mathrm{K}$ & $14 / 15$ & $\mathrm{D} / \mathrm{D}$ & $-1-$ & $+1+$ & $+1-$ & $-1-$ & $-1-$ & $+/+$ & $+/+$ & $-1-$ & $30 / 36$ \\
\hline II-1 & $\mathrm{K} / \mathrm{K}$ & $14 / 14$ & $\mathrm{D} / \mathrm{D}$ & $-1-$ & $+1+$ & $+1+$ & $-1-$ & $-1-$ & $+1+$ & $+/+$ & $-1-$ & $36 / 36$ \\
\hline \multirow[t]{13}{*}{ II -2} & $\mathrm{~K} / \mathrm{K}$ & $14 / 14$ & $\mathrm{D} / \mathrm{D}$ & $-1-$ & $+1+$ & $+1+$ & $-1-$ & $-1-$ & $+1+$ & $+/+$ & $-1-$ & $36 / 36$ \\
\hline & A & 14 & I & + & + & + & - & - & + & + & - & 36 \\
\hline & B & 14 & I & + & + & - & - & - & + & + & - & 42 \\
\hline & $\mathrm{C}$ & 14 & I & + & - & - & + & - & + & + & + & 34 \\
\hline & D & 15 & I & + & - & - & - & - & + & - & - & 46 \\
\hline & $\mathrm{E}^{\ddagger}$ & 14 & I & + & - & + & - & + & + & + & - & 34 \\
\hline & $F$ & 14 & D & - & + & + & - & - & + & + & - & 38 \\
\hline & G & 14 & I & + & - & + & - & - & + & + & - & 36 \\
\hline & $\mathbf{H}$ & 14 & I & + & - & - & - & - & + & - & - & 48 \\
\hline & I & 14 & D & - & + & + & - & - & + & + & - & 40 \\
\hline & $\mathbf{J}^{\ddagger}$ & 14 & I & + & - & - & + & + & + & + & + & 34 \\
\hline & $\mathrm{K}$ & 14 & D & - & + & + & - & - & + & + & - & 36 \\
\hline & L & 15 & D & - & + & - & - & - & + & + & - & 30 \\
\hline
\end{tabular}

* Individuals heterozygous for the $\operatorname{Arg}_{3531} \rightarrow$ Cys mutation. ${ }^{\ddagger}$ Haplotypes associated with the mutation. The boxed regions highlight the differences between these two haplotypes.

As can be seen from Table IV, the mutant $\mathrm{Cys}_{3531}$ allele is associated in both kindreds with the presence of an ApaLl site at nucleotide 416 . Hence the apoB molecules with a Cys at residue 3531 will also have a Thr at residue 71 and bind with low affinity to MB19. There were three individuals with the mutation who were available to study and who were heterozygous for the ApaL1 RFLP. These were subjects I-4 and II-3 from the L. S. kindred and I-1 from the A. C. kindred. At the time blood samples were collected, none of the three individuals were taking lipid-lowering drugs. In addition to these three subjects, the Thr/Ile LDL ratio was also determined for control LDL samples from two Thr/Ile heterozygotes. The percentage ratios of Thr/Ile LDL particles for these two were 51:49 and 49:51, very close to the expected ratio of 50:50. For the three subjects heterozygous for the 3531 mutation, this ratio was significantly different, and in each case there was an accumulation of the mutant $\mathrm{Cys}_{3531}$ particles (the $\mathrm{Thr}_{71}$ isoforms). The ratios were 63:38 (I-4, L. S. kindred), 55:45 (II-3, L. S. kindred), and 60:40 (I-1, A. C. kindred). All values are the average of duplicate determinations. Therefore, with these three individuals, the defective LDL had accumulated to a mean ratio of 59:41 over normal LDL.
The binding affinity of LDL for the LDL receptor was also determined for these three patients. The values obtained were $54.1,58.1$, and $58.7 \%$ of reference LDL, respectively. These were the average binding affinities of the mixture of normal and defective particles, but since the fraction of LDL particles that contain the defective $\mathrm{Cys}_{3531}$ form was known, it was possible to calculate accurately its binding affinity. ${ }^{2}$ In the three cases, the calculated binding affinities of the defective Cys $\mathrm{Cy}_{3531}$ LDL were $26.5,24.1$, and $31.3 \%$, respectively (mean \pm SE $=27.3 \pm 2.1 \%$ ).

apoB haplotype analysis. Haplotype analysis, using $10 \mathrm{apoB}$ genetic markers, showed that the apoB $\mathrm{Arg}_{3531} \rightarrow$ Cys alleles are different in the two kindreds (Table IV). In the L. S. and A. C. kindreds, the Cys allele is associated with haplotypes $\mathrm{E}$ and $\mathrm{J}$, respectively. The differences between these two haplotypes reside at the loci for the XbaI, BfaI (residue 2712), and Eco57I (residue 4311) RFLPs.

2. The calculation was performed as follows: (fraction abnormal $\times \chi$ ) $+($ fraction normal $\times 1)=R 2 / R 1$, where $R 2 / R 1$ is the value obtained from the binding assay for the patient's LDL and $\chi$ is the calculated value of $R 2 / R 1$ for the abnormal particles. 


\section{Discussion}

We report the discovery, using SSCP analysis, of a new apoB mutation in codon 3531 that causes an arginine to cysteine substitution. Using a competitive dual-label binding assay and a laser light scattering technique, we have shown that this mutation results in a defect in the binding of LDL to the LDL receptor that leads to an accumulation in plasma of the defective LDL. LDL prepared from eight subjects, all heterozygous for the $\operatorname{Arg}_{3531} \rightarrow$ Cys mutation, had a mean affinity for the LDL receptor that was $62.9 \%$ of control LDL. The three individuals available for study who were heterozygous for the $\mathrm{Thr}_{71} / \mathrm{Ile}_{71}$ polymorphism were shown to accumulate the defective $\mathrm{Cys}_{3531}$ LDL in their plasma to a 59:41 percentage ratio over normal LDL particles. From these two pieces of information, the binding affinity of the defective $\mathrm{Cys}_{3531}$ LDL particles was calculated as $27 \%$ of normal.

The amount of abnormal LDL was reported to be typically $70 \%$, and the amount of normal LDL was $30 \%$ in patients with familial ligand-defective apoB caused by the apoB $\operatorname{Arg}_{3500} \rightarrow \mathrm{Gln}$ mutation (44). In the present study, LDL from patients heterozygous for the apoB $\mathrm{Arg}_{3500} \rightarrow \mathrm{Gln}$ mutation were found to have $35.8 \%$ of the binding affinity of control LDL, close to the value of $32 \%$ reported by Innerarity et al. (45) and a value of $35.7 \%$ reported by Friedl et al. (44). Thus, based on a binding affinity of $35 \%$, it can be calculated that the $\operatorname{Gln}_{3500}$ particles have $<10 \%$ of normal binding affinity. This is consistant with the report that LDL from one patient with the $\operatorname{Arg}_{3500} \rightarrow \mathrm{Gln}$ mutation, when highly enriched for the defective $\operatorname{Gln}_{3500}$ variant particles, was reported to bind to the LDL receptor with $<10 \%$ of normal affinity (45). Hence the $\operatorname{Arg}_{3531} \rightarrow$ Cys mutation results in a somewhat less severe impairment of binding than does the $\operatorname{Arg}_{3500} \rightarrow$ Gln mutation. This is consistent with the lipid analysis that indicates less of an increase in serum and LDL cholesterol levels as a result of the $\operatorname{Arg}_{3531} \rightarrow$ Cys mutation than that caused by the $\mathrm{Arg}_{3500} \rightarrow$ Gln mutation.

The reason for the $73 \%$ decrease in binding affinity due to the 3531 mutation is unclear. However, it is thought that the defect in binding in the case of the 3500 mutation may be the result of a conformational change in apoB-100 that involves redisposition of a number of charged residues rather than loss of a single receptor-interactive residue (46).

We have shown that eight patients who are heterozygous for the $\operatorname{Arg}_{3531} \rightarrow$ Cys mutation have a mean adjusted level of LDL cholesterol that is $66 \mathrm{mg} / \mathrm{dl}$ higher than control values and $45 \mathrm{mg} / \mathrm{dl}$ higher than the values of their unaffected family members. This difference is a reflection of other factors, possibly genetic, present in the two kindreds besides the $\operatorname{Arg}_{3531} \rightarrow$ Cys mutation and reflects the lack of simple cosegregation of this defect with the hypercholesterolemia. Simple cosegregation of the LDL receptor locus with the hypercholesterolemia was not apparent, ruling out a monogenic receptor defect common to the hypercholesterolemic individuals. Additional studies should reveal many patients with the $\mathrm{Arg}_{3531} \rightarrow$ Cys mutation, allowing a more accurate measure to be made of the effect it has on the level of serum cholesterol. The clinical presentation may or may not be the same as that in patients with the $\operatorname{Arg}_{3500} \rightarrow \mathrm{Gln}$ mutation. The effect of the $\operatorname{Arg}_{3531} \rightarrow$ Cys mutation, however, appears to be less than that of the $\operatorname{Arg}_{3500} \rightarrow$ Gln mutation, which in turn is somewhat less than that of many LDL receptor gene defects seen in FH. It has previously been reported that 41 patients with the $\operatorname{Arg}_{3500} \rightarrow$ Gln mutation had a mean level of total cholesterol of $269 \mathrm{mg} / \mathrm{dl}$ (45), close to the age- and gender-adjusted mean value of $265 \mathrm{mg} / \mathrm{dl}$ for the 6 patients that we studied in this report. In the earlier study (45), LDL cholesterol levels of $\operatorname{Arg}_{3500} \rightarrow$ Gln heterozygotes were $71 \mathrm{mg} / \mathrm{dl}$ higher than control values, which is somewhat lower than the $95 \mathrm{mg} /$ dl elevation seen in the present study. Innerarity and his coworkers point out that other workers have observed higher mean levels of cholesterol in $\operatorname{Arg}_{3500} \rightarrow$ Gln patients that are closer to values seen with FH heterozygotes, though the reasons for these differences are not clear. LDL cholesterol levels in FH heterozygotes over the age of $20 \mathrm{yr}$ are elevated by $175 \mathrm{mg} / \mathrm{dl}$ over normal values (1).

The frequency of the $\operatorname{Arg}_{3500} \rightarrow$ Gln mutation in an unselected population has been estimated from a four-center study, one of which was San Francisco, to be 1 in 543 (0.00184) (47). Since we have found 12 probands with the 3500 mutation out of our clinic population of 1,368 (a frequency of 1 in 114), it follows that selection for hyperlipidemia has increased the frequency by a factor of about 4.8 -fold. Hence, the occurrence of two probands with the $\operatorname{Arg}_{3531} \rightarrow$ Cys mutation is compatible with a frequency in the general population in San Francisco of $\sim 1$ in 3,000 .

apoB haplotype analysis of two kindreds shows the presence of two different apoB $\mathrm{Arg}_{3531} \rightarrow$ Cys alleles, which is perhaps not surprising in the light of the differing ethnic origins of these families. The two haplotypes differ at three markers, and since two are upstream and one is downstream of the mutation, it is likely that the mutations arose independently. Alternatively, two recombination events would have had to occur if the mutation arose only once. Two of the RFLP markers that differ, BfaI (codon 2712) and Eco57I (codon 4311), have been independently linked to the $\operatorname{Ag}(\mathrm{x} / \mathrm{y})$ polymorphism $(35,36)$, and the third (XbaI) is in linkage disequilibrium with both the BfaI and the Eco57I RFLPs (36).

Initially it was found that all probands with the $\operatorname{Arg}_{3500} \rightarrow \mathrm{Gln}$ mutation, in several populations in Europe and North America, had the same apoB haplotype, indicating a single mutational event $(33,48)$. Recently, a different haplotype was reported in Germany, providing evidence for an independent $\operatorname{Arg}_{3500} \rightarrow \mathrm{Gln}$ mutation (49). A unique haplotype, associated with the $\mathrm{Gln}_{3500}$ allele in a Chinese patient, indicated either an independent mutation or a recombination in the $3^{\prime}$ end of the gene (50).

It has been estimated for other genes that the frequency of mutations in CG dinucleotides is between 10 and 20 times the average rate (51). The $\mathrm{Arg}_{3531} \rightarrow$ Cys and $\mathrm{Arg}_{3500} \rightarrow$ Gln mutations are both transitions in CG dinucleotides, as is the MspI polymorphism in codon 3611 , and all three involve substitutions for arginine residues. It would not, therefore, be surprising if other mutations in the putative apoB LDL receptor-binding domain involve mutated arginine codons. The discovery of the $\operatorname{Arg}_{3531} \rightarrow$ Cys mutation and other ligand-defective mutations of apoB will enable a better understanding of the sequences involved in receptor binding. There is evidence $(3,4)$ that various ligand defects are significant in the etiology of primary hypercholesterolemia, and it has now been shown that certain LDL subspecies, particularly small dense LDL, have impaired ligand properties (52). Hence, it is probable that changes in the conformational disposition of apoB secondary to alterations of the lipid content of LDL may be responsible for impaired binding 
in a significant number of cases. In these instances no mutation in apoB will be found.

\section{Acknowledgments}

Monoclonal antibodies MB19 and MB47 were provided by Linda K. Curtiss (Research Institute of Scripps Clinic, La Jolla, CA.)

This work was supported by National Institutes of Health grants HL-14237 (Arteriosclerosis Specialized Center of Research), HL28481, HL-45753-02, GM-13914, and DK-40355, by University of California Tobacco Related Disease Research Program grants 1RT-177 and 2RT-172, by a gift from Donald and Susan Schleicher, and by a gift from the Joseph Drown Foundation. C.R. Pullinger and C.M. Mendel were recipients of a Grant-in-Aid from the American Heart Association, California Affiliate. L.K. Hennessy was a recipient of a scholarship from the Achievement Rewards for College Scientists Foundation (Northern California Chapter). J.E. Chatterton was supported by U. S. Public Health Service National Research Service Awards HL07386-15 and CA09056-17.

\section{References}

1. Goldstein, J. L., and M. S. Brown. 1989. Familial hypercholesterolemia. In C. R. Scriver, A. L. Beaudet, W. S. Sly, and D. Valle, editors. The Metabolic Basis of Inherited Disease, 6th ed. McGraw-Hill, New York. 1215-1250.

2. Kontula, K., U. M. Koivisto, P. Koivisto, and H. Turtola. 1992. Molecular genetics of familial hypercholesterolaemia-common and rare mutations of the low density lipoprotein receptor gene. Ann. Med. 24:363-367.

3. Vega, G. L., and S. M. Grundy. 1986. In vivo evidence for reduced binding of low-density lipoproteins to receptors as a cause of primary moderate hypercholesterolemia. J. Clin. Invest. 78:1410-1414.

4. Innerarity, T. L., K. H. Weisgraber, K. S. Arnold, R. W. Mahley, R. M. Krauss, G. L. Vega, and S. M. Grundy. 1987. Familial defective apolipoprotein B-100: low density lipoproteins with abnormal receptor binding. Proc. Natl. Acad. Sci. USA. 84:6919-6923.

5. Soria, L. F., E. H. Ludwig, H. R. G. Clarke, G. L. Vega, S. M. Grundy, and B. J. McCarthy. 1989. Association between a specific apolipoprotein B mutation and familial defective apolipoprotein B-100. Proc. Natl. Acad. Sci. USA. 86:587-591.

6. Weisgraber, K. H., T. L. Innerarity, Y. M. Newhouse, S. G. Young, K. S. Arnold, R. M. Krauss, G. L. Vega, S. M. Grundy, and R. W. Mahley. 1988. Familial defective apolipoprotein B-100: enhanced binding of monoclonal antibody MB47 to abnormal low density lipoproteins. Proc. Natl. Acad. Sci. USA. 85:9758-9762.

7. Myant, N. B., J. J. Gallagher, B. L. Knight, S. N. McCarthy, J. Frostegård, J. Nilsson, A. Hamsten, P. Talmud, and S. E. Humphries. 1991. Clinical signs of familial hypercholesterolemia in patients with familial defective apolipoprotein B-100 and normal low density lipoprotein receptor function. Arteriosclerosis Thromb. 11:691-703.

8. Corsini, A., B. J. McCarthy, A. Granata, L. F. Soria, S. Fabtappie, R. Bernini C., L. Romano, R. Fumagalli, and A. L. Catapano. 1991. Familial defective apo B-100, characterization of an Italian family. Eur. J. Clin. Invest. 21:389-397.

9. Geisel, J., T. Schleifenbaum, K. Oette, and B. Weisshaar. 1992. Familial defective apolipoprotein B-100 in 12 subjects and their kindred. Eur. J. Clin. Chem. Clin. Biochem. 30:729-736.

10. Rauh, G., C. Keller, B. Kormann, F. Spengel, H. Schuster, G. Wolfram, and N. Zöllner. 1992. Familial defective apolipoprotein $B_{100}$ : clinical characteristics of 54 cases. Atherosclerosis. 92:233-241.

11. Bertolini, S., D. A. Coviello, P. Masturzo, E. Zucchetto, N. Elicio, R. Balestreri, G. Orecchini, S. Calandra, and S. Humphries. 1992. RFLPs of the LDL-receptor gene: their use in the diagnosis of FH and in evaluation of different levels of gene expression on normal subjects. Eur. J. Epidemiol. 8 (Suppl. to No. 2): $18-25$

12. Orita, M., Y. Suzuki, T. Sekiya, and K. Hayashi. 1989. Rapid and sensitive detection of point mutations and DNA polymorphisms using the polymerase chain reaction. Genomics. 5:874-879.

13. Orita, M., H. Iwahana, H. Kanazawa, K. Hayashi, and T. Sekiya. 1989. Detection of polymorphisms of human DNA by gel electrophoresis as singlestrand conformation polymorphisms. Proc. Natl. Acad. Sci. USA. 86:2766-2770.

14. Economou, E. P., H. H. Kazazian, Jr., and S. E. Antonarakis. 1992. Detection of mutations in the factor VIII gene using single-strand conformational polymorphism (SSCP). Genomics. 13:909-911.

15. Plieth, J., F. Rininsland, M. Schlösser, D. N. Cooper, and J. Reiss. 1992. Single-strand conformation polymorphism (SSCP) analysis of exon 11 of the
CFTR gene reliably detects more than one third of non-DF508 mutations in German cystic fibrosis patients. Hum. Genet. 88:283-287.

16. Zietkiewicz, E., D. Sinnett, C. Richer, G. Mitchell, M. Vanasse, and D. Labuda. 1992. Single-strand conformational polymorphisms (SSCP): detection of useful polymorphisms at the dystrophin locus. Hum. Genet. 89:453-456.

17. Knott, T. J., R. J. Pease, L. M. Powell, S. C. Wallis, S. C. Rall, Jr., T. L. Innerarity, B. Blackhart, W. H. Taylor, Y. Marcel, R. Milne, D. Johnson, M. Fuller, A. J. Lusis, B. J. McCarthy, R. W. Mahley, B. Levy-Wilson, and J. Scott. 1986. Complete protein sequence and identification of structural domains of human apolipoprotein B. Nature (Lond.). 323:734-738.

18. Yang, C.-Y., S.-H. Chen, S. H. Gianturco, W. A. Bradley, J. T. Sparrow, M. Tanimura, W.-H. Li, D. A. Sparrow, H. DeLoof, M. Rosseneu, F.-S. Lee, Z.-W. Gu, J. A. M. Gotto, and L. Chan. 1986. Sequence, structure, receptorbinding domains and internal repeats of human apolipoprotein B-100. Nature (Lond.). 323:738-742.

19. Pease, R. J., R. W. Milne, W. K. Jessup, A. Law, P. Provost, J.-C. Fruchart, R. T. Dean, Y. L. Marcel, and J. Scott. 1990. Use of bacterial expression cloning to localize the epitopes for a series of monoclonal antibodies against apolipoprotein B100. J. Biol. Chem. 265:553-568.

20. Dunning, A. M., R. Houlston, J. Frostegard, J. Revill, J. Nilsson, A. Hamsten, P. Talmud, and S. Humphries. 1991. Genetic evidence that the putative receptor binding domain of apolipoprotein B (residues 3130 to 3630) is not the only region of the protein involved in interaction with the low density lipoprotein receptor. Biochim. Biophys. Acta. 1096:231-237.

21. Fantappiè, S., A. Corsini, A. Sidoli, P. Uboldi, A. Granata, T. Zanelli, P. Rossi, S. Marcovina, R. Fumagalli, and A. L. Catapano. 1992. Monoclonal antibodies to human low density lipoprotein identify distinct areas on apolipoprotein B-100 relevant to the low density lipoprotein-receptor interaction. J. Lipid Res. 33:1111-1121.

22. Avoustin, P., H. Mostachi, B. Perret, J. P. Cambou, F. Cambien, and C. Depreval. 1992. A very conservative region of ApoB-100 in the putative binding region to the LDL receptor in the Toulouse population. Hum. Genet. 90:460463.

23. Mendel, C. M. 1994. A novel assay for comparing affinity constants of ligands with small differences in affinity: application to low density lipoproteins. Anal. Biochem. 216:328-334.

24. Bell, G. I., J. H. Karam, and W. J. Rutter. 1981. Polymorphic DNA region adjacent to the 5' end of the human insulin gene. Proc. Natl. Acad. Sci. USA. 78:5759-5763.

25. Pullinger, C. R., E. Hillas, D. A. Hardman, G. C. Chen, J. M. Naya-Vigne J. A. Iwasa, R. L. Hamilton, J.-M. Lalouel, R. R. Williams, and J. P. Kane. 1992. Two apolipoprotein B gene defects in a kindred with hypobetalipoproteinemia, one of which results in a truncated variant, apoB-61, in VLDL and LDL. J. Lipid Res. 33:699-710.

26. Pullinger, C. R., B. R. Zysow, L. K. Hennessy, P. H. Frost, M. J. Malloy, and J. P. Kane. 1993. Molecular cloning and characteristics of a new apolipoprotein-C-II mutant identified in 3 unrelated individuals with hypercholesterolemia and hypertriglyceridemia. Hum. Mol. Genet. 2:69-74.

27. Lipid Research Clinics' Program. 1980. Population Studies Data Book: Vol. I, The Prevalence Study. U. S. Department of Health and Human Services, Public Health Service, National Institutes of Health (NIH publication number 801527), Washington, DC.

28. Sambrook, J., E. F. Fritsch, and T. Maniatis. 1989. Molecular Cloning. A Laboratory Manual. Cold Spring Harbor Laboratory, Cold Spring Harbor, NY.

29. Bilheimer, D. W., S. Eisenberg, and R. I. Levy. 1972. The metabolism of very low density lipoproteins. I. Preliminary in vitro and in vivo observations. Biochem. Biophys. Acta. 260:212-221.

30. Young, S., S. Bertics, L. Curtiss, D. Casal, and J. Witztum. 1986. Monoclonal antibody MB19 detects genetic polymorphism in human apolipoprotein B. Proc. Natl. Acad. Sci. USA. 83:1101-1105.

31. Ma, Y., X. Wang, R. Bütler, and V. N. Schumaker. 1989. Bsp 12861 restriction fragment length polymorphism detects $\mathrm{Ag}(\mathrm{c} / \mathrm{g})$ locus of human apolipoprotein B in all 17 persons studied. Arteriosclerosis. 9:242-246.

32. Young, S. G., and S. T. Hubl. 1989. An ApaLI restriction site polymorphism is associated with the MB19 polymorphism in apolipoprotein B. J. Lipid Res. 30:443-449.

33. Ludwig, E. H., and B. J. McCarthy. 1990. Haplotype analysis of the human apolipoprotein B mutation associated with familial defective apolipoprotein B 100 . Am. J. Hum. Genet. 47:712-720.

34. Wang, X. B., P. Schlapfer, Y. H. Ma, R. Butler, J. Elovson, and V. N. Schumaker. 1988. Apolipoprotein $\mathrm{B}$ : the $\mathrm{Ag}(\mathrm{al} / \mathrm{d})$ immunogenetic polymorphism coincides with a T-to-C substitution at nucleotide 1981, creating an Alu-I restriction site. Arteriosclerosis. 8:429-435.

35. Wu, M.-J., E. Bütler, R. Bütler, and V. N. Schumaker. 1991. Identification of the base substitution responsible for the $\mathrm{Ag}(\mathrm{x} / \mathrm{y})$ polymorphism of apolipoprotein B-100. Arteriosclerosis Thromb. 11:379-384.

36. Dunning, A. M., H.-H. Renges, C.-F. Xu, R. Peacock, R. Brasseur, G Laxer, M. J. Tikkanen, R. Bütler, N. Saha, A. Hamsten, M. Rosseneu, P. Talmud, 
and S. E. Humphries. 1992. Two amino acid substitutions in apolipoprotein B are in complete allelic association with the antigen group $(x / y)$ polymorphism: evidence for little recombination in the $3^{\prime}$ end of the human gene. Am. J. Hum. Genet. 50:208-221.

37. Warnich, L., M. J. Kotze, E. Langenhoven, and A. E. Retief. 1992. Detection of a frequent polymorphism in exon 10 of the low-density lipoprotein receptor gene. Hum. Genet. 89:362.

38. Leitersdorf, E., and H. H. Hobbs. 1988. Human LDL receptor gene: HincII polymorphism detected by gene amplification. Nucleic Acids Res. 16:7215.

39. Cavanaugh, J. A., and S. Easteal. 1991. A HaelII polymorphism in the 3' untranslated region of the low density lipoprotein receptor (LDLR) gene. Nucleic Acids Res. 19:6663.

40. Kotze, M. J., E. Langenhoven, E. Dietzsch, and A. E. Retief. 1987. A RFLP associated with the low-density lipoprotein receptor gene (LDLR). Nucleic Acids Res. 15:376.

41. Zuliani, G., and H. H. Hobbs. 1990. Dinucleotide repeat polymorphism at the $3^{\prime}$ end of the LDL receptor gene. Nucleic Acids Res. 18:4300.

42. Hixon, J. E., and D. T. Vernier. 1990. Restriction isotyping of human apolipoprotein $\mathrm{E}$ by gene amplification and cleavage with HhaI. J. Lipid Res. 31:545-548.

43. Pagnan, A., R. J. Havel, J. P. Kane, and L. Kotite. 1977. Characterization of human very low density lipoproteins containing two electrophoretic populations: double pre-beta lipoproteinemia and primary dysbetalipoproteinemia. J. Lipid Res. 18:613-622.

44. Friedl, W., E. Ludwig, M. Balestra, K. Arnold, B. Paulweber, F. Sandhofer, B. McCarthy, and T. Innerarity. 1991. Apolipoprotein B gene mutations in Austrian subjects with heart disease and their kindred. Arteriosclerosis Thromb. 11:371-378.
45. Innerarity, T. L., R. W. Mahley, K. H. Weisgraber, T. P. Bersot, R. M. Krauss, G. L. Vega, S. M. Grundy, W. Friedl, J. Davignon, and B. J. McCarthy. 1990. Familial defective apolipoprotein B-100: a mutation of apolipoprotein B that causes hypercholesterolemia. J. Lipid Res. 31:1337-1349.

46. Lund-Katz, S., T. L. Innerarity, K. S. Arnold, L. K. Curtiss, and M. C. Phillips. 1991. ${ }^{13} \mathrm{C}$ NMR evidence that substitution of glutamine for arginine 3500 in familial defective apolipoprotein B-100 disrupts the conformation of the receptor-binding domain. J. Biol. Chem. 266:2701-2704.

47. Innerarity, T. L., M. E. Balestra, K. S. Arnold, R. W. Mahley, G. L. Vega, S. M. Grundy, and S. G. Young. 1988. Isolation of defective receptor-binding low density lipoproteins from subjects with familial defective apolipoprotein B100. Arteriosclerosis. 8:551a. (Abstr.)

48. Rauh, G., H. Schuster, J. Fischer, C. Keller, G. Wolfram, and N. Zollner. 1991. Familial defective apolipoprotein B-100: haplotype analysis of the arginine 3500-glutamine mutation. Atherosclerosis. 88:219-226.

49. Rauh, G., H. Schuster, C. K. Schewe, G. Stratmann, C. Keller, G. Wolfram, and $N$. Zollner. 1993. Independent mutation of arginine $(3500) \rightarrow$ glutamine associated with familial defective apolipoprotein B-100. J. Lipid Res. 34:799-805.

50. Bersot, T. P., S. J. Russell, S. R. Thatcher, N. K. Pomernacki, R. W. Mahley, K. H. Weisgraber, T. L. Innerarity, and C. S. Fox. 1993. A unique haplotype of the apolipoprotein B-100 allele associated with familial defective apolipoprotein B-100 in a Chinese man discovered during a study of the prevalence of this disorder. J. Lipid Res. 34:1149-1154.

51. Youssoufian, H., S. E. Antonarakis, W. Bell, A. M. Griffin, and H. H. J. Kazazian. 1988. Nonsense and missense mutations in hemophilia A: estimate of the relative mutation rate at CG dinucleotides. Am. J. Hum. Genet. 42:718-725.

52. Nigon, F., P. Lesnik, M. Rouis, and M. Chapman. 1991. Discrete subspecies of human low density lipoproteins are heterogeneous in their interaction with the cellular LDL receptor. J. Lipid Res. 32:1741-1753. 